\title{
Gambaran Postur Kerja dan Keluhan Muskuloskeletal pada Pegawai Tata Laksana di Universitas Islam Bandung
}

\author{
Luthfianisa Rayyani, ${ }^{1}$ Yuniarti, ${ }^{2}$ Caecielia, ${ }^{3}$ Susan Fitriyana, ${ }^{4}$ Budiman $^{5}$ \\ ${ }^{1}$ Program Studi Pendidikan Dokter, ${ }^{2}$ Departemen Anatomi, ${ }^{3}$ Departemen Fisiologi, \\ 4,5Departemen Ilmu Kesehatan Masyarakat, Fakultas Kedokteran Universitas Islam Bandung
}

\begin{abstract}
Abstrak
Ketidaksesuaian faktor ergonomi akan mengakibatkan kesalahan dalam postur kerja dan umumnya disertai gejala kelainan/keluhan musculoskeletal yang merupakan gangguan pada sendi, otot, tendon, kerangka, tulang rawan, ligamen, dan saraf yang umumnya berupa rasa nyeri. Tujuan penelitian mengetahui gambaran postur kerja dan keluhan muskuloskeletal pada pegawai tata laksana di Universitas Islam Bandung. Jenis penelitian merupakan observasional deskriptif dengan pendekatan cross sectional. Subjek penelitian sebanyak 50 orang pegawai tata laksana di Universitas Islam Bandung yang berada di bawah naungan Kopsyakardos dan sudah bekerja lebih dari 1 tahun. Sampel penelitian diambil dengan cara melakukan observasi mengggunakan employee rapid entire body assessment (REBA) working sheet untuk menilai postur kerja, kemudian melakukan pengisian kuesioner dengan menggunakan nordic body map (NBM) untuk menilai keluhan muskuloskeletal. Penelitian dilakukan Maret-Mei 2018. Hasil penelitian menunjukkan bahwa sebagian besar postur kerja responden berada pada kelompok risiko sedang sebanyak 39 orang (78\%), kelompok risiko tinggi sebanyak 6 orang (12\%), dan kelompok risiko rendah sebanyak 5 orang (10\%). Keluhan muskuloskeletal paling banyak mengeluh sakit pada bahu kanan, bahu kiri, dan pinggang. Kesalahan postur kerja yang tidak sesuai dengan kaidah ergonomi, dilakukan secara berulang-ulang, dan dalam jangka waktu yang lama akan menimbulkan keluhan muskuloskeletal.
\end{abstract}

Kata kunci: Keluhan muskuloskeletal, nordic body map (NBM), pegawai tata laksana, postur kerja, rapid entire body assessment (REBA)

\section{Description of Work Posture and Musculoskeletal Complaint on the Cleaning Service in University of Islam Bandung}

\begin{abstract}
Ergonomic factor incompatibility will lead to errors in the work posture and generally accompanied by symptoms of musculoskeletal disorder which is a disorder of the joints, muscles, tendons, skeletons, cartilage, ligaments, and nerves are generally a pain. The purpose of this study was to know the description of work posture and musculoskeletal complaints on the cleaning service in University of Islam Bandung. This method in research type is descriptive observational by using cross sectional. Research subjects as many as 50 cleaning service personnel in University of Islam Bandung under the Kopsyakardos and has worked for more than 1 year. Research sample was taken by observation using Employee Rapid Entire Body Assessment (REBA) working sheet to assess work posture, then fill out questionnaires using Nordic Body Map (NBM) to assess musculoskeletal complaints. The study was held during March-April 2018. The results showed that most of respondent's work posture was in moderate risk group as much as 39 people (78\%), in high risk group as many as 6 people (12\%), and in low risk group as many as 5 people (10\%). Musculoskeletal complaints most often complain of pain in the right shoulder, left shoulder, and waist. Work posture errors that are not in accordance with ergonomic rules, carried out repeatedly, and in the long term will cause musculoskeletal complaints.
\end{abstract}

Keywords: Cleaning service, musculoskeletal disorder, nordic body map (NBM), rapid entire body assessment (REBA), work posture

Korespondensi: Luthfianisa Rayyani, Program Studi Pendidikan Dokter Fakultas Kedokteran, Universitas Islam Bandung. Jl. Tamansari No. 22, 40116, Kota Bandung, Provinsi Jawa Barat. Hp: o813 1259 9976, E-mail: lulu13new@gmail.com 


\section{Pendahuluan}

Ergonomi merupakan ilmu terapan yang mempelajari dan mencari pemecahan persoalan yang menyangkut faktor manusia dalam proses produksi. Secara praktis, ergonomi sebagai ilmu rekayasa untuk mendesain atau mengatur kerja. Ruang lingkup ilmu ergonomi meliputi sejumlah aplikasi beberapa ilmu lain yang saling mendukung, seperti ilmu anatomi, ilmu faal, ilmu psikologi, ilmu teknik, dan sejumlah ilmu yang secara bersama-sama menempatkan faktor manusia sebagai fokus utama dalam rangkaian kerja yang terdapat dalam sistem kerja. Sistem kerja yang tidak ergonomis sering kali kurang mendapat perhatian atau dianggap sepele, contohnya pada cara, sikap, dan posisi kerja yang tidak benar, fasilitas kerja yang tidak sesuai, serta faktor lingkungan kerja yang kurang mendukung. Hal ini secara sadar ataupun tidak akan berpengaruh terhadap produktivitas, efisiensi, dan efektivitas pekerja dalam menyelesaikan pekerjaannya. Penerapan ergonomi yang kurang diperhatikan dapat menyebabkan keluhan muskuloskeletal. ${ }^{1}$

World Health Organization (WHO) tahun 2010 menyatakan keluhan muskuloskeletal dengan istilah work related musculoskeletal disorders (WMSDs), yaitu merupakan keluhan rasa nyeri yang dirasakan di daerah leher, bagian atas punggung, bahu, lengan atau tangan yang dirasakan oleh pekerja biasanya yang berkepanjangan yang akhirnya dapat menimbulkan kecacatan dan juga mengurangi keterampilan dan produktivitas kerja. ${ }^{2}$

International of Labour Organization (ILO), United States Occupational Safety and Health Administration (OSHA) tahun 2010 memperkirakan lebih dari 600.000 pekerja mengalami keluhan muskuloskeletal akibat kerja. ${ }^{3}$ Berdasar atas hasil survei Departemen Kesehatan Republik Indonesia dalam profil kesehatan tahun 2005 menunjukkan bahwa sekitar $40,5 \%$ penyakit yang diderita pekerja berhubungan dengan pekerjaannya dan gangguan kesehatan yang dialami pekerja menurut studi yang dilakukan terhadap 428 pekerja di 12 kabupaten/ kota di Indonesia umumnya berupa gangguan musculosceletal disorders (16\%), kardiovaskular (8\%), gangguan saraf (6\%), gangguan pernapasan (3\%), serta gangguan telinga hidung dan tenggorokan $(1,5 \%){ }^{4}$ Hajrah dkk. ${ }^{5}$ dalam penelitiannya di RSUP Dr. Wahidin Sudirohusodo Makassar terhadap pegawai cleaning service didapatkan hasil keluhan muskuloskeletal berat $(49,1 \%)$ dan keluhan muskuloskeletal ringan (50,9\%). Jalajuwita dan Paskarini ${ }^{4}$ dalam penelitiannya di Unit Pengelasan PT X Bekasi menggunakan metode rapid entire body assessment (REBA) terhadap pekerja pengelasan didapatkan hasil keluhan muskuloskeletal rendah 32\% (risiko REBA sedang) dan keluhan muskuloskeletal sedang 68\% (risiko REBA sedang), keluhan muskuloskeletal rendah $11 \%$ (risiko REBA tinggi), keluhan muskuloskeletal sedang 56\% (risiko REBA tinggi), dan keluhan muskuloskeletal tinggi 33\% (risiko REBA tinggi).

Pegawai sebagai tata laksana di Universitas Islam Bandung adalah pegawai yang berada di bawah naungan Kopsyakardos (Koperasi Syariah Karyawan dan Dosen) di Universitas Islam Bandung. Pada wawancara sebelum penelitian dilakukan, para pekerja sering mengeluhkan nyeri pada bagian anggota tubuhnya karena pada saat melakukan aktivitas kerja, postur kerja yang dilakukan tidak baik, hal tersebut dilakukan berulang-ulang sehingga terjadilah keluhan muskuloskeletal.

Berdasar atas latar belakang di atas maka peneliti tertarik untuk mengetahui gambaran postur kerja dan keluhan muskuloskeletal pada pegawai tata laksana di Universitas Islam Bandung tahun 2018.

\section{Metode}

Jenis penelitian ini adalah penelitian descriptive observasional dengan pendekatan cross sectional. Teknik pengambilan sampel menggunakan total sampling dengan besar sampel 50 orang. Penelitian ini dilaksanakan di Universitas Islam Bandung pada bulan Maret sampai dengan bulan Mei tahun 2018.

Data penilaian postur kerja menggunakan rapid entire body assessment (REBA). rapid entire body assessment (REBA) membagi bagian tubuh menjadi 6 bagian, yaitu trunk (badan), neck (leher), legs (kaki), upper arms (lengan atas), lower arms (lengan bawah), dan arm (pergelangan tangan). Langkah-langkah yang harus dilakukan untuk mendapatkan skor REBA secara keseluruhan adalah mengambil foto dari postur kerja yang akan dianalisis, kemudian mengestimasi sudut dari enam bagian tubuh yang dianalisis, lalu mengubah informasi sudut menjadi klasifikasi postur menurut REBA, dan terakhir menentukan beberapa adjustment sesuai dengan metode REBA. ${ }^{6}$

Penilaian REBA menggunakan lembar pengamatan seperti pada Gambar 1 dan Gambar 2.

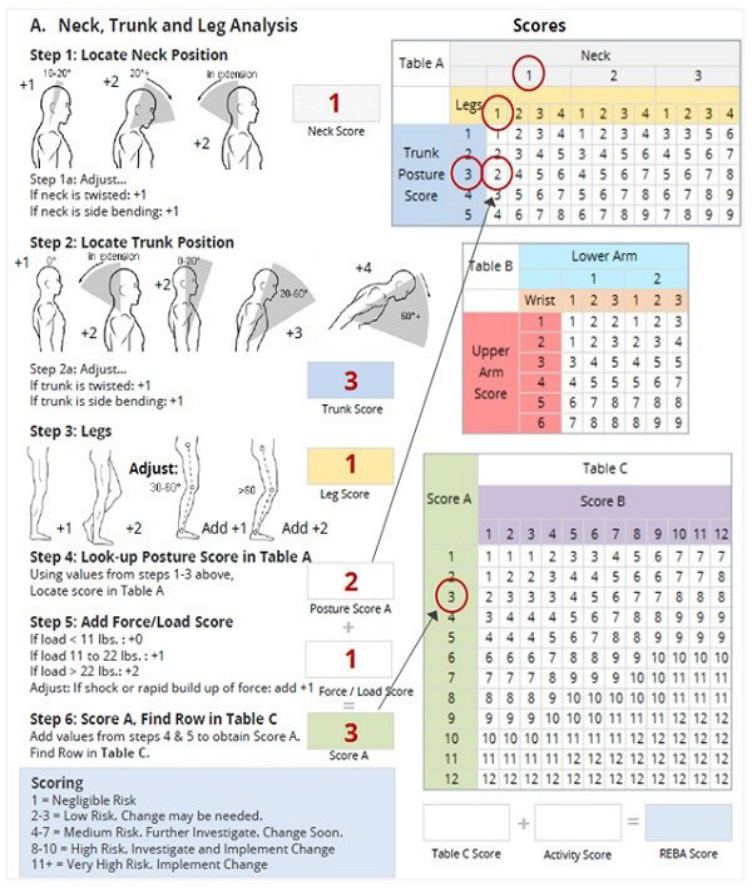

Gambar 1 Employee REBA Working Sheet (Bagian A) 


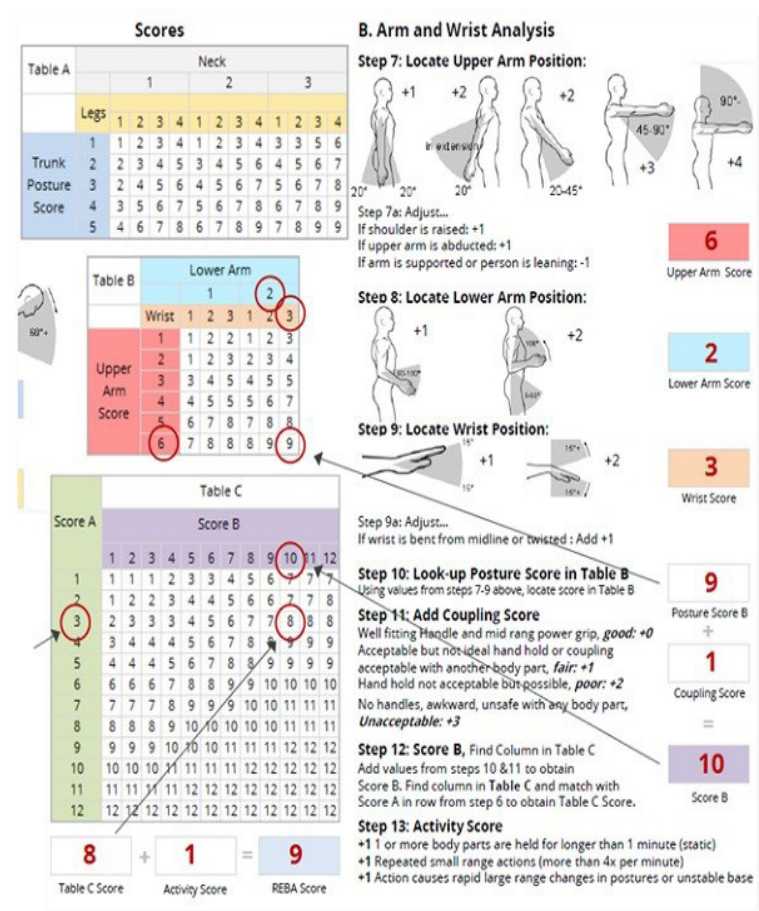

Gambar 2 Employee REBA Working Sheet (Bagian B) 7

Tabel level risiko berdasar atas metode rapid entire body assessment (REBA) sebagaimana dijelaskan pada Tabel 1.

Tabel 1 Action Level dan Tindakan Perbaikan ${ }^{7}$

\begin{tabular}{cccc}
\hline $\begin{array}{c}\text { Action } \\
\text { Level }\end{array}$ & $\begin{array}{c}\text { Skor } \\
\text { REBA }\end{array}$ & Level Risiko & $\begin{array}{c}\text { Tindakan } \\
\text { Perbaikan }\end{array}$ \\
\hline 0 & 1 & $\begin{array}{c}\text { Dapat } \\
\text { diabaikan }\end{array}$ & Tidak perlu \\
& & Rendah & Mungkin perlu \\
1 & $2-3$ & Sedang & Perlu \\
2 & $4-7$ & Tinggi & Perlu segera \\
3 & $8-10$ & Sangat tinggi & Perlu saat ini juga \\
4 & $11-15$ &
\end{tabular}

Dari tabel risiko di atas dapat diketahui dengan nilai REBA yang didapatkan dari hasil perhitungan sebelumnya dapat diketahui level risiko yang terjadi dan perlu atau tidaknya tindakan yang dilakukan untuk perbaikan. Perbaikan kerja yang mungkin dilakukan antara lain berupa perancangan ulang peralatan kerja berdasar atas prinsip-prinsip ergonomi.

Data penilaian keluhan muskuloskeletal berdasar atas nordic body map (NBM) merupakan salah satu alat ukur subjektif berupa kuesioner yang digunakan untuk mengetahui bagian-bagian otot yang mengalami keluhan mulai dari rasa tidak sakit sampai sangat sakit. Kuesioner ini menggunakan gambar tubuh manusia yang dibagi menjadi 9 bagian tubuh utama, yaitu leher, bahu, punggung bagian atas, siku, punggung bagian bawah, pergelangan tangan, paha, lutut, dan tumit.

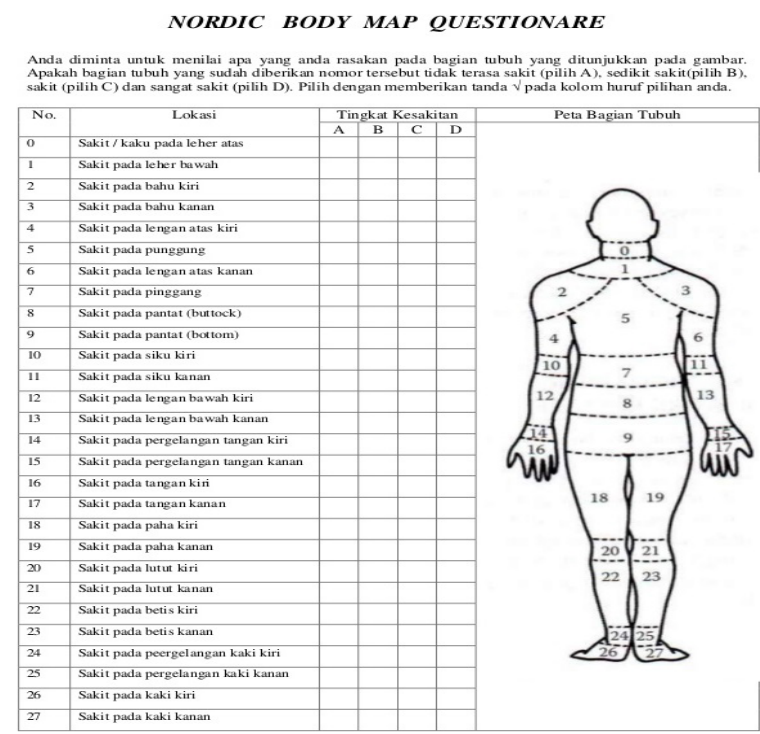

Gambar 3 Kuesioner Nordic Body Map ${ }^{8}$

Dari 9 bagian tubuh tersebut kemudian diperinci menjadi 28 bagian tubuh seperti yang terlihat pada Gambar 3. Tingkat kesakitan pekerja berdasar atas metode nordic body map (NBM) sebagaimana dijelaskan pada Tabel 2.

Tabel 2 Tingkat Kesakitan Pekerja Berdasar atas (NBM)

\begin{tabular}{ccc}
\hline \multicolumn{2}{c}{ Keterangan } \\
\hline A & No pain & Tidak nyeri \\
B & Moderately pain & Cukup nyeri \\
C & Painful & Nyeri \\
D & Very painful & Sangat nyeri \\
\hline
\end{tabular}

Berdasar atas tabel di atas dapat dijelaskan sebagai berikut:

$\mathrm{A}=$ responden tidak mengeluhkan nyeri sama sekali yang dirasakan selama melakukan pekerjaan (tidak nyeri).

$\mathrm{B}=$ responden merasakan sedikit keluhan atau rasa nyeri pada bagian tubuh tertentu, tetapi belum mengganggu pekerjaan (cukup nyeri).

$\mathrm{C}=$ responden merasakan keluhan atau rasa nyeri pada bagian tubuh tertentu dan sudah mengganggu pekerjaan, tetapi rasa nyeri dapat hilang setelah dilakukan istirahat (nyeri).

$\mathrm{D}=$ responden merasakan keluhan sangat nyeri pada bagian tubuh tertentu dan nyeri tidak segera hilang meskipun telah beristirahat yang lama atau bahkan dibutuhkan obat pereda nyeri (sangat nyeri).

Penelitian ini telah disetujui oleh Komite Etik Penelitian Kesehatan Fakultas Kedokteran Universitas Islam Bandung dengan Nomor: 203/Komite Etik.FK/ III/2018. 


\section{Hasil}

Karakteristik jenis kelamin, usia, dan postur kerja responden berdasar atas REBA dapat dilihat pada Tabel 3 .

Tabel 3 Jenis Kelamin, Usia, dan Postur Kerja Responden berdasar atas REBA

\begin{tabular}{lcc}
\hline Karakteristik & $\mathbf{n = 5 0}$ & Persen (\%) \\
\hline $\begin{array}{l}\text { Jenis kelamin } \\
\text { Laki-laki }\end{array}$ & 49 & 98 \\
Perempuan & 1 & 2 \\
Usia (tahun) & & \\
20-30 & 15 & 30 \\
31-40 & 18 & 36 \\
41-50 & 16 & 32 \\
51-60 & 1 & 2 \\
Karakteristik REBA & & \\
Risiko rendah & 5 & 10 \\
Risiko sedang & 39 & 78 \\
Risiko tinggi & 6 & 12 \\
\hline
\end{tabular}

Tabel di atas menunjukkan bahwa sebagian besar responden laki-laki 49 orang (98\%), usia responden 31-40 tahun, yaitu sebanyak 18 orang (36\%), dan postur kerja responden berada pada kelompok risiko sedang sebanyak 39 orang $(78 \%)$.

Pada saat dilakukan observasi postur kerja pada responden, jenis pekerjaan yang sedang dilakukan berbeda-beda, seperti yang terlihat pada Tabel 4 .

Tabel 4 Jenis Pekerjaan Responden Saat dilakukan Observasi

\begin{tabular}{clcc}
\hline No & \multicolumn{1}{c}{ Jenis Pekerjaan } & n=5o & $\begin{array}{c}\text { Persen } \\
\text { (\%) }\end{array}$ \\
\hline 1 & Mengelap meja & 6 & 12 \\
2 & Menyapu lantai & 12 & 24 \\
3 & Menghapus papan tulis & 1 & 2 \\
4 & Mengepel lantai & 19 & 38 \\
5 & Membereskan kursi & 1 & 2 \\
6 & Menyimpan berkas ke lemari & 1 & 2 \\
7 & Mencuci piring & 2 & 4 \\
8 & Mengelap kaca & 3 & 6 \\
9 & Menyikat dinding kamar mandi & 3 & 6 \\
10 & Membersihkan alat & 1 & 2 \\
11 & Memotong rumput & 1 & 2 \\
\hline
\end{tabular}

Tabel di atas menunjukan bahwa sebagian besar pekerjaan yang dilakukan oleh responden saat sedang dilakukan observasi postur kerja adalah mengepel lantai sebanyak 19 orang (38\%).

Jenis pekerjaan yang dilakukan oleh responden saat dilakukan observasi postur kerja berbedabeda sehingga dalam menilai postur kerja pun ada sedikit perbedaan disesuaikan dengan postur kerja yang dilakukan oleh responden tersebut saat sedang melakukan pekerjaannya maka hal tersebut dapat memengaruhi nilai skor REBA, seperti yang terlihat pada Tabel 5 .

Tabel 5 Postur Kerja berdasar atas Jenis Pekerjaan dengan Level Risiko REBA

\begin{tabular}{|c|c|c|c|c|c|}
\hline \multirow{2}{*}{ No } & \multirow{2}{*}{$\begin{array}{c}\text { Jenis } \\
\text { Pekerjaan }\end{array}$} & \multirow{2}{*}{$\underset{\text { (n) }}{\text { Jumlah }}$} & \multicolumn{3}{|c|}{ Risiko (n) } \\
\hline & & & Rendah & Sedang & Tinggi \\
\hline 1 & Mengelap meja & 6 & o & 5 & 1 \\
\hline 2 & Menyapu lantai & 12 & o & 9 & 3 \\
\hline 3 & $\begin{array}{l}\text { Menghapus } \\
\text { papan tulis }\end{array}$ & 1 & o & 1 & o \\
\hline 4 & Mengepel lantai & 19 & 3 & 15 & 1 \\
\hline 5 & $\begin{array}{l}\text { Membereskan } \\
\text { kursi }\end{array}$ & 1 & 0 & 1 & 0 \\
\hline 6 & $\begin{array}{l}\text { Menyimpan } \\
\text { berkas ke lemari }\end{array}$ & 1 & $\mathrm{o}$ & 1 & o \\
\hline 7 & Mencuci piring & 2 & 2 & o & o \\
\hline 8 & Mengelap kaca & 3 & $\mathrm{o}$ & 3 & o \\
\hline 9 & $\begin{array}{l}\text { Menyikat dinding } \\
\text { kamar mandi }\end{array}$ & 3 & $\mathrm{o}$ & 2 & 1 \\
\hline 10 & $\begin{array}{l}\text { Membersihkan } \\
\text { alat }\end{array}$ & 1 & $\mathrm{o}$ & 1 & o \\
\hline 11 & $\begin{array}{l}\text { Memotong } \\
\text { rumput }\end{array}$ & 1 & $\mathrm{o}$ & 1 & o \\
\hline
\end{tabular}

Tabel di atas menunjukkan bahwa pada responden level risiko REBA rendah terdapat pada jenis pekerjaan mengepel lantai dan mencuci piring, walaupun jenis pekerjaan mengepel lantai dapat berisiko sedang dan tinggi. Pada level risiko REBA sedang terdapat pada semua jenis pekerjaan kecuali pada jenis pekerjaan mencuci piring. Pada level risiko REBA tinggi terdapat pada jenis pekerjaan mengelap meja, menyapu lantai, mengepel lantai, dan menyikat kamar mandi.

Berikut ini adalah hasil penelitian mengenai gambaran keluhan muskuloskeletal berdasar atas metode nordic body map (NBM). Hasil penelitian dijelaskan pada Tabel 6.

Tabel 6 memperlihatkan bahwa keluhan muskuloskeletal responden pada kelompok tidak nyeri sebagian besar pada lokasi siku kanan sebanyak 46 orang (92\%), pada kelompok cukup nyeri sebagian besar pada lokasi pinggang sebanyak 25 orang (50\%), pada kelompok nyeri sebagian besar pada lokasi pinggang sebanyak 8 orang (16\%), dan pada kelompok sangat nyeri sebagian besar pada lokasi bahu kiri, bahu kanan, dan pinggang sebanyak dua orang (4\%). 


\begin{tabular}{|c|c|c|c|c|c|}
\hline l & $\begin{array}{l}\text { Keluhan Muskulosk } \\
\text { NBM }\end{array}$ & letal & & & ata \\
\hline No & Lokasi & $\mathbf{A}$ & B & $\mathbf{C}$ & D \\
\hline 1 & Sakit leher atas & 36 & 10 & 4 & o \\
\hline 2 & Sakit leher bawah & 42 & 6 & 2 & o \\
\hline 3 & Sakit bahu kiri & 34 & 10 & 4 & 2 \\
\hline 4 & Sakit bahu kanan & 35 & 11 & 2 & 2 \\
\hline 5 & Sakit lengan atas kiri & 35 & 11 & 4 & o \\
\hline 6 & Sakit punggung & 31 & 16 & 2 & 1 \\
\hline 7 & Sakit lengan atas kanan & 36 & 10 & 3 & 1 \\
\hline 8 & Sakit pinggang & 15 & 25 & 8 & 2 \\
\hline 9 & Sakit pantat (buttock) & 43 & 6 & o & 1 \\
\hline 10 & Sakit pantat (bottom) & 43 & 6 & o & 1 \\
\hline 11 & Sakit siku kiri & 45 & 5 & o & o \\
\hline 12 & Sakit siku kanan & 46 & 4 & o & o \\
\hline 13 & Sakit lengan bawah kiri & 38 & 11 & 1 & o \\
\hline 14 & Sakit lengan bawah kanan & 41 & 8 & 1 & o \\
\hline 15 & $\begin{array}{l}\text { Sakit pergelangan tangan } \\
\text { kiri }\end{array}$ & 38 & 11 & o & 1 \\
\hline 16 & $\begin{array}{l}\text { Sakit pergelangan tangan } \\
\text { kanan }\end{array}$ & 40 & 9 & o & 1 \\
\hline 17 & Sakit tangan kiri & 41 & 7 & 2 & o \\
\hline 18 & Sakit tangan kanan & 40 & 7 & 2 & 1 \\
\hline 19 & Sakit paha kiri & 42 & 5 & 3 & o \\
\hline 20 & Sakit paha kanan & 42 & 5 & 3 & o \\
\hline 21 & Sakit lutut kiri & 36 & 11 & 2 & 1 \\
\hline 22 & Sakit lutut kanan & 39 & 8 & 2 & 1 \\
\hline 23 & Sakit betis kiri & 28 & 14 & 7 & 1 \\
\hline 24 & Sakit betis kanan & 28 & 14 & 7 & 1 \\
\hline 25 & Sakit pergelangan kaki kiri & 40 & 7 & 3 & o \\
\hline 26 & $\begin{array}{l}\text { Sakit pergelangan kaki } \\
\text { kanan }\end{array}$ & 39 & 7 & 3 & 1 \\
\hline 27 & Sakit kaki kiri & 39 & 8 & 3 & o \\
\hline 28 & Sakit kaki kanan & 38 & 9 & 2 & 1 \\
\hline
\end{tabular}

$$
\begin{array}{ll}
\text { Ket: } & \text { A }=\text { tidak nyeri } \\
& \mathrm{B}=\text { cukup nyeri } \\
& \mathrm{C}=\text { nyeri } \\
\mathrm{D} & =\text { sangat nyeri }
\end{array}
$$

\section{Pembahasan}

Usia merupakan salah satu faktor yang memengaruhi gejala keluhan muskuloskeletal. Berdasar atas hasil yang didapatkan bahwa usia pada pegawai tata laksana di Universitas Islam Bandung menunjukkan bahwa usia responden berkisar antara 23-53 tahun. Menurut Depkes RI tahun 2013 usia produktif 15-54 tahun sehingga dalam penelitian ini usia responden termasuk ke dalam usia kerja produktif. Menurut Betti dkk. yang dikutip Tarwaka ${ }^{9}$ kekuatan maksimal otot terjadi pada saat usia 20-29 tahun. Pada usia mencapai 60 tahun rerata kekuatan otot menurun sampai 20\% dan dari faktor lain dikarenakan oleh postur kerja yang tidak ergonomi sehingga mengakibatkan musculoskeletal disorders. Sejalan dengan pendapat Muslim dan Santoso dalam Fathoni dkk. ${ }^{10}$ di Purbalingga bahwa keluhan nyeri punggung mulai dirasakan pada usia 20-40 tahun yang diperkirakan disebabkan oleh faktor degenerasi dan beban statik serta osteoporosis.

Kegiatan pengangkutan (aktivitas fisik pekerja) berhubungan dengan beban objek, gerakan repetitive postur kerja yang dapat berpotensi menimbulkan keluhan muskuloskeletal. Terlebih pada pegawai tata laksana tidak ada aturan khusus yang diberlakukan terkait pekerjaan sehingga postur kerja yang terbentuk pada saat melakukan pekerjaannya berbeda-beda sesuai dengan selera tiap-tiap pekerja dan umumnya cenderung melakukan postur kerja yang menjauhi sikap alamiah tubuh seperti kepala terangkat sebagian, punggung yang terlalu membungkuk, pergerakan tangan yang terangkat sehingga berkontribusi terjadi keluhan di leher, bahu, punggung, dan anggota gerak. ${ }^{1}$

Hal ini juga disertai dengan statis otot yang cukup lama akan menyebabkan penyumbatan aliran darah dan akan mengakibatkan pada bagian tubuh tersebut kekurangan oksigen dan glukosa dari darah. Selain itu, tubuh akan menghasilkan sisa metabolisme seperti asam laktat yang tidak dapat diangkut keluar akibat peredaran darah yang terganggu sehingga menumpuk dan menimbulkan rasa nyeri sehingga dapat menyebabkan beban pada otot dan tendon yang dapat menyebabkan kelelahan lebih cepat sehingga memungkinkan terjadi keluhan muskuloskeletal. ${ }^{11}$

Pada enam orang responden yang saat dilakukan observasi sedang mengelap meja, didapatkan hasil sebanyak lima orang termasuk ke dalam kategori REBA risiko sedang dan sebanyak 1 orang termasuk ke dalam kategori REBA risiko tinggi.

Postur kerja responden posisi punggung dan kepala membungkuk sehingga membentuk sudut sehingga saat dilakukan analisis REBA diketahui memiliki level risiko sedang sehingga perlu dilakukan tindakan perbaikan. Postur kerja responden posisi punggung dan kepala lebih membungkuk dan posisi kaki tidak tegap dalam mempertahankan batang tubuh sehingga saat dilakukan analisis REBA memiliki level risiko tinggi sehingga perlu segera dilakukan tindakan perbaikan.

Pada 12 orang responden yang pada saat dilakukan observasi sedang menyapu lantai, didapatkan hasil sebanyak 9 orang termasuk ke dalam kategori REBA risiko sedang dan sebanyak 3 orang termasuk ke dalam kategori REBA risiko tinggi.

Postur kerja responden pada posisi punggung dan kepala membungkuk sehingga membentuk sudut, posisi kaki tidak tegap dalam mempertahankan batang tubuh sehingga saat dilakukan analisis REBA memiliki level risiko sedang sehingga perlu dilakukan tindakan perbaikan. Postur kerja responden posisi punggung dan kepala lebih membungkuk dan posisi kaki tidak tegap dalam mempertahankan batang tubuh sehingga saat dilakukan analisis REBA memiliki level risiko tinggi sehingga perlu segera dilakukan tindakan perbaikan. 
Pada seorang responden yang saat dilakukan observasi sedang menghapus papan tulis, didapatkan hasil termasuk ke dalam kategori REBA risiko sedang. Postur kerja responden posisi kaki terlihat terbuka lebar sehingga saat sedang menghapus papan tulis tumpuan kaki dalam menopang batang tubuh tidak merata sehingga pada saat dilakukan analisis REBA memiliki level risiko sedang sehingga perlu dilakukan tindakan perbaikan.

Pada 19 orang responden yang saat dilakukan observasi sedang mengepel lantai, didapatkan hasil sebanyak 3 orang termasuk ke dalam kategori REBA risiko rendah, sebanyak 15 orang termasuk ke dalam kategori REBA risiko sedang, dan sebanyak 1 orang termasuk ke dalam kategori REBA risiko tinggi.

Postur kerja responden posisi kaki terlihat tegap dan tidak terbuka lebar, tetapi lutut sedikit membungkuk sehingga membentuk sudut maka saat dilakukan analisis REBA memiliki level risiko rendah sehingga mungkin perlu dilakukan tindakan perbaikan. Postur kerja responden posisi kaki terlihat tidak tegap dan terbuka lebar sehingga beban batang tubuh tidak tersebar merata dan tertumpu di kaki sebelah kiri maka saat dilakukan analisis REBA memiliki level risiko sedang sehingga perlu dilakukan tindakan perbaikan. Postur kerja responden posisi kaki terlihat tidak tegap dan terbuka lebar sehingga beban batang tubuh tidak tersebar merata dan tertumpu di kaki sebelah kanan, cara memegang alat pel pun antara lengan kiri dan lengan kanan terlalu jauh sehingga saat postur kerja tersebut dipertahankan dalam waktu yang lama dan berulang-ulang dapat menyebabkan keluhan muskuloskeletal pada bagian bahu sehingga saat dilakukan analisis REBA memiliki level risiko tinggi sehingga perlu segera dilakukan tindakan perbaikan.

Pada seorang responden yang pada saat dilakukan observasi sedang membereskan kursi, didapatkan hasil termasuk ke dalam kategori REBA risiko sedang.

Postur kerja responden posisi kaki terlihat tidak tegap sehingga beban batang tubuh tidak tersebar merata dan hanya tertumpu pada satu kaki, yaitu kaki sebelah kiri, posisi kepala leher terlalu membungkuk sehingga membentuk sudut maka saat dilakukan analisis REBA memiliki level risiko sedang sehingga perlu dilakukan tindakan perbaikan.

Pada seorang responden yang pada saat dilakukan observasi sedang menyimpan berkas ke lemari, didapatkan hasil termasuk ke dalam kategori REBA risiko sedang. Postur kerja responden posisi kaki terlihat jinjit atau berdiri dengan ujung jari sehingga beban batang tubuh tidak tersebar merata dan hanya tertumpu pada satu kaki, yaitu kaki sebelah kanan, posisi kepala leher terlalu menengadah sehingga membentuk sudut maka saat dilakukan analisis REBA memiliki level risiko sedang sehingga perlu dilakukan tindakan perbaikan.

Pada dua orang responden yang saat dilakukan observasi sedang mencuci piring, didapatkan hasil termasuk ke dalam kategori REBA risiko rendah. Postur kerja responden posisi kepala leher tidak terlalu menunduk, punggung tegap, posisi kaki walaupun terbuka lebar, tetapi tidak terlalu berisiko karena kaki menopang beban batang tubuh seimbang (tumpuan terbagi rata) sehingga saat dilakukan analisis REBA memiliki level risiko rendah sehingga mungkin perlu dilakukan tindakan perbaikan.

Pada tiga orang responden yang saat dilakukan observasi sedang mengelap kaca, didapatkan hasil termasuk ke dalam kategori REBA risiko sedang. Postur kerja responden posisi kepala leher menunduk, punggung membungkuk, posisi kaki jinjit atau menahan beban batang tubuh dengan jari-jari kaki sehingga saat dilakukan analisis REBA memiliki level risiko sedang sehingga perlu dilakukan tindakan perbaikan.

Pada tiga orang responden yang saat dilakukan observasi sedang menyikat dinding kamar mandi, didapatkan hasil sebanyak 2 orang termasuk ke dalam kategori REBA risiko sedang dan sebanyak 1 orang termasuk ke dalam kategori REBA risiko tinggi.

Postur kerja responden posisi leher sedikit menengadah, kaki terlihat tegap dan tidak terbuka lebar sehingga beban batang tubuh dapat tersebar merata (tidak tertumpu pada salah satu kaki) walapun dalam keadaan jongkok, postur kerja tidak terlalu jauh menjauhi batang tubuh terlihat dari sudut yang terbentuk tidak terlalu besar maka saat dilakukan analisis REBA memiliki level risiko sedang sehingga perlu dilakukan tindakan perbaikan. Responden posisi kaki terlihat tidak tegap dan lutut sedikit membungkuk walaupun tidak membentuk sudut tetapi beban batang tubuh tidak tersebar merata, cara menyikat dinding kamar mandi nya pun posisi lengan kanan terlalu menjauhi batang tubuh terlihat dari sudut yang terbentuk sangat besar sehingga saat postur kerja tersebut dipertahankan dalam waktu yang lama dan berulang-ulang dapat menyebabkan adanya keluhan muskuloskeletal pada bagian bahu sehingga saat dilakukan analisis REBA memiliki level risiko tinggi sehingga perlu segera dilakukan tindakan perbaikan.

Pada seorang responden yang saat dilakukan observasi sedang membersihkan alat, didapatkan hasil termasuk ke dalam kategori REBA risiko sedang.

Postur kerja responden posisi kaki terlihat tegap dan walapun kaki terbuka lebar tetapi sejajar dengan bahu sehingga beban batang tubuh tersebar merata, posisi kepala leher terlalu menengadah sehingga membentuk sudut maka saat dilakukan analisis REBA diketahui memiliki level risiko sedang sehingga perlu dilakukan tindakan perbaikan.

Pada seorang responden yang saat dilakukan observasi sedang memotong rumput, didapatkan hasil termasuk ke dalam kategori REBA risiko sedang. Postur kerja responden posisi kaki terlihat tegap dan walapun kaki terbuka lebar tetapi sejajar dengan bahu sehingga beban batang tubuh tersebar merata, posisi kepala leher menunduk sehingga membentuk sudut, dan posisi bahu terangkat ke atas maka saat dilakukan analisis REBA memiliki level risiko sedang sehingga perlu dilakukan tindakan perbaikan.

\section{Simpulan}

Berdasar atas hasil penelitian ini, disimpulkan bahwa postur kerja pegawai tata laksana di Universitas Islam Bandung periode Maret-April 2018 kebanyakan termasuk ke dalam kelompok yang risiko sedang 
yang diperlukan tindakan perubahan. Keluhan muskuloskeletal paling banyak dikeluhkan sakit pada bahu kanan, bahu kiri, dan pinggang.

\section{Ucapan Terima Kasih}

Ucapan terima kasih kepada semua pegawai tata laksana di Universitas Islam Bandung yang telah meluangkan waktu berharganya untuk ikut berpartisipasi dalam penelitian ini.

\section{Daftar Pustaka}

1. Budiono, Sugeng AM. Bunga rampai hiperkes dan KK higiene perusahaan ergonomi kesehatan kerja keselamatan kerja. Semarang: Badan Penerbit Universitas Diponegoro Semarang; 2013.

2. Djatmiko RD. Keselamatan dan kesehatan kerja. Edisi ke-1. Yogyakarta: Gava Media; 2016.

3. Bureau of Labour Statistics (BLS). Musculoskeletal disorders and days away from work in 2007. [diunduh 18 April 2018]. Tersedia dari: https:// www.bls.gov/opub/ted/2008/dec/wk1/arto2. htm \#: :text=The\%20rate\%20of\%20MSD\%20 injuries,MSD\%20average\%20for\% 20 all\%20 occupations.

4. Jalajuwita RN, Paskarini I. Hubungan posisi kerja dengan keluhan muskuloskeletal pada Unit Pengelasan PT X Bekasi. IJOSH. 2015;4:33-42.

5. Hajrah H, Bedu S, Russeng SS. Faktor yang berhubungan dengan gangguan muskuloskeletal pada cleaning service di RSUP Dr. Wahidin Sudirohusodo Makasar. [diunduh 12 April 2018]. Tersedia dari: https://core.ac.uk/download/ pdf/25491576.pdf

6. Tarwaka. Ergonomi industri. Surakarta: Harapan Press; 2013.

7. Hedge A. REBA employee assessment worksheet; 2015. [diunduh 14 April 2018]. Tersedia dari: https://ergo-plus.com/wp-content/uploads/ REBA.pdf

8. Tarwaka, Solichul, Lilik. Ergonomi untuk keselamatan, kesehatan kerja, dan produktivitas. Edisi ke-1. Surakarta: UNIBA Press; 2004.

9. Tarwaka. Ergonomi industri. Dasar dasar pengetahuan ergonomi dan aplikasi di tempat kerja. Edisi ke-2. Surakarta: Harapan Press Solo; 2014.

10. Fathoni H, Handoyo, Swasti KG. Hubungan sikap dan posisi kerja dengan low back pain pada perawat RSUD Purbalingga. J Nurse. 2012 Jul;7(2):88-9.

11. Ulfah N, Harwanti S, Nurcahyo PJ. Work attitude and musculoskeletal disorders risk in laundry worker. Kes Mas. 2014;8(7):313-8. 